\title{
M. paratuberculosis Heat Shock Protein 65 and Human Diseases: Bridging Infection and Autoimmunity
}

\author{
Coad Thomas Dow \\ Chippewa Valley Eye Clinic, Wisconsin and Eye Research Institute, University of Wisconsin-Madison, \\ 2715 Damon Street, Eau Claire, WI 54701, USA \\ Correspondence should be addressed to Coad Thomas Dow, ctdow@me.com
}

Received 13 June 2012; Revised 27 August 2012; Accepted 29 August 2012

Academic Editor: Kamal D. Moudgil

Copyright ( $\odot 2012$ Coad Thomas Dow. This is an open access article distributed under the Creative Commons Attribution License, which permits unrestricted use, distribution, and reproduction in any medium, provided the original work is properly cited.

Mycobacterium avium subspecies paratuberculosis (MAP) is the known infectious cause of Johne's disease, an enteric inflammatory disease mostly studied in ruminant animals. MAP has also been implicated in the very similar Crohn's disease of humans as well as sarcoidosis. Recently, MAP has been associated with juvenile sarcoidosis (Blau syndrome), autoimmune diabetes, autoimmune thyroiditis, and multiple sclerosis. While it is intuitive to implicate MAP in granulomatous diseases where the microbe participates in the granuloma, it is more difficult to assign a role for MAP in diseases where autoantibodies are a primary feature. MAP may trigger autoimmune antibodies via its heat shock proteins. Mycobacterial heat shock protein 65 (HSP65) is an immunodominant protein that shares sequential and conformational elements with several human host proteins. This molecular mimicry is the proposed etiopathology by which MAP stimulates autoantibodies associated with autoimmune (type 1) diabetes, autoimmune (Hashimoto's) thyroiditis, and multiple sclerosis. This paper proposes that MAP is a source of mycobacterial HSP65 and acts as a trigger of autoimmune disease.

\section{Introduction}

The term "molecular mimicry" is accredited to Damian in 1964. He was first to suggest that antigenic elements of microorganisms may resemble antigenic elements of their host. Damian suggested that this similarity served as a defense mechanism of a microorganism from the host's immune system and prevented the development of immune response to the microorganism, thereby protecting it from host defense [1]. Over time the term "molecular mimicry" was given a different meaning, namely, antigenic elements of microorganisms may trigger an autoimmune response that harms the host. The concept of molecular mimicry is based on a structural similarity between a pathogen and self. The similarity could be expressed as shared amino acid sequences or similar conformational structure between a pathogen and self-antigens. Molecular mimicry has become a very popular explanation for the frequent association of infection with autoimmune disease [2].
Under cellular stress such as heat, ethanol, heavy metals, endotoxins, and inflammatory processes, heat shock proteins (HSPs) are rapidly synthesized, increasing their concentration in the intracellular compartment as well as on the cell surface [3-9]. Heat shock proteins are found in virtually all life forms and are closely linked to the immune response. HSP65 of microorganisms is an immunodominant antigen. In human mycobacterial infection, for example, it has been estimated that up to $40 \%$ of the T-cell response is directed against this single protein $[10,11]$. Although there is great homology between mycobacterial HSP65 among the species, genotyping of the $3^{\prime}$ end of the HSP65 gene has proven to unambiguously distinguish between the $M$. avium complex of mycobacteria as well as the cattle and sheep strains of M. paratuberculosis [12]. Immune responses to these proteins have been described in both infectious [13] and autoimmune diseases $[14,15]$ in human and animal models, suggesting that they could be attractive target molecules for interfering with these processes $[16,17]$. 
This paper proposes that Mycobacterium avium ss. paratuberculosis (MAP) is a source of mycobacterial HSP65 and acts as a driver of autoimmunity [18].

\section{MAP}

MAP is a Gram-positive, acid-fast staining small rod-shaped bacterium. As with members of the Mycobacteriaceae genus, it has a unique cell wall structure rich in complex lipids. The thick and chemically distinctive cell wall of mycobacteria is largely responsible for the robust nature of these bacteria, both within the host cell and in the environment. The pathogenic potential of mycobacteria is correlated with their growth rate. Paradoxically, slow-growing mycobacteria are more virulent than fast-growing mycobacteria. With the exception of Mycobacterium leprae (the cause of leprosy in humans), which cannot be cultured in vitro, MAP has the slowest growth rate of pathogenic mycobacteria. After isolation from infected animals and grown under optimal conditions colonies of MAP are typically not visible for 3 months or more [19]. MAP causes a chronic granulomatous inflammation of the intestines in ruminant animals called Johne's disease. Mostly studied in dairy cattle, goats, and sheep, MAP also causes a chronic inflammation of the intestines in beef cattle and in a wide variety of other domestic and wild ruminants. MAP-induced enteric inflammation has been found in monogastric animals including dogs and pigs as well as four different types of subhuman primates-macaques, baboons, gibbons, and cotton-top tamarins [20]. A majority of the dairy herds in the United States and Europe have MAP infected animals within the herd [21].

\section{MAP and Human Exposure}

Infected cows shed up to $1.6 \times 10^{7}$ organisms per 2 grams of manure $(0.07 \mathrm{oz})$ - a dose large enough to infect a calf. A single high-shedding animal can excrete up to 15 gallons of such contaminated manure per day-a staggering 25,000 infective doses per day [22]. MAP is present in pasteurized milk [23, 24], infant formula made from pasteurized milk [25], surface water $[26,27]$, soil [26], cow manure "lagoons" that leach into surface water, cow manure in both solid and liquid forms that is applied as fertilizer to agricultural land [28, 29], and municipal tap water [29, 30], providing multiple routes of transmission to humans.

\section{MAP and Human Granulomatous Disease: Crohn's and Sarcoidosis}

In addition to Johne's disease of animals, MAP is the putative cause of the strikingly similar Crohn's disease of humans. Although there has been a century-long debate, the role of MAP in Crohn's is evolving from controversial to compelling [31-33]. The major source of the debate is that conventional methods of detecting bacteria_-namely, culture and stainare largely ineffective in detecting MAP. However, with newer laboratory techniques, primarily PCR, evidence of MAP is readily found in Crohn's tissues $[34,35]$. In a study that evaluated the inflammatory bowel disease of attendants of goat herds where caprine Johne's disease is endemic, MAP was detected in the attendants compared to controls; the risk was correlated with the duration of association with the endemic goat herd [36]. The DNA of MAP can be identified within the granulomas of Crohn's biopsies [37] and, with extreme care and patience, MAP can be grown from the gut and blood of Crohn's patients [38-40]. In limited series, antimycobacterial therapy directed at MAP has been shown to have a favorable effect on patients with Crohn's disease [41].

Moreover, MAP has been historically linked is sarcoidosis; a multisystem inflammatory disease in which DNA evidence of MAP has been found (sporadically) in sarcoid granulomas [42]. Juvenile sarcoidosis (Blau syndrome) is an inherited granulomatous disease of children. The DNA of MAP was detected from every sample in a small series of archived tissues [43].

\section{Genetics of Mycobacterial Infection and Autoimmunity}

A complete discussion of shared genetic association to mycobacterial infection and autoimmune disease is beyond the scope of this paper. However, the role of the SLC11a1 gene is worth discussing in some depth. Natural resistanceassociated macrophage protein 1 (NRAMP1) is now referred to as SLC11a1 (solute carrier 11a1). The gene that encodes for this protein is recognized as having a role in the susceptibility of humans and animals to a number of infections, including mycobacterial infections, and is associated with a number of autoimmune diseases as well.

The product of the SLC11a1 gene modulates the cellular environment in response to activation by intracellular pathogens by acidifying the phagosome thus killing the pathogen [44]. As such, it plays a role in host innate immunity [45]. Mutation of SLC11al impairs phagosome acidification yielding a permissive environment for the persistence of intracellular bacteria [46].

SLC11a1 polymorphisms are associated with paratuberculosis in cattle [47], goats [48], and sheep [49]. When researchers at the Belgium Pasteur Institute developed a murine model for MAP infection, they created an SLC11A1 defect mouse [50]. Given the pivotal roles that SLC11A1 plays in innate immunity and, as such, is not surprising that the relationship between polymorphisms in SLC11A1 and a number of mycobacterial as well as autoimmune diseases has been explored [51]. Associations have been found with leprosy [52], tuberculosis [53], and the aforementioned sarcoidosis [54]. Additionally, SLC11a1 associations have been found with rheumatoid arthritis [55], visceral leishmaniasis [56], multiple sclerosis $[57,58]$, inflammatory bowel disease [59-61], and type 1 diabetes mellitus (T1DM) $[62,63]$.

\section{MAP and Type 1 Diabetes, Autoimmune Thyroiditis, and Multiple Sclerosis}

While it is not difficult to envision a role for MAP in human disease where there is a granuloma, it is more difficult to 
divine a role for MAP in diseases that feature autoantibodies. This divide is bridged by the concept that MAP HSP65 mimics host protein elements. An example is that of MAP as a proposed infectious trigger of autoimmune diabetes. T1DM is an autoimmune disease manifest by progressive $\mathrm{T}$ cell-mediated autoimmune destruction of insulin-producing beta cells in the pancreatic islets of Langerhans [64]. In 2005, Dow postulated a causative role for MAP in the T1DM [65]. Sechi et al. in 2007 found the DNA of MAP in the blood of autoimmune (type 1) patients but not nonautoimmune (type 2) diabetics [66-68]. (Sechi also found an association of polymorphisms of the SLC11a1 gene and MAP in T1DM patients [61].) The link connecting MAP and T1DM: MAP HSP65 mimic the host pancreatic glutamic acid decarboxylase (GAD) [69]. Similar mechanisms are proposed for the role of MAP in autoimmune (Hashimoto's) thyroiditis [70, 71] and multiple sclerosis [72].

\section{Discussion}

Not specific to MAP but to mycobacteria in general, mycobacterial HSP has been found in several additional autoimmune diseases [73]: the mycobacterial HSP65 has been implicated in the pathogenesis of rheumatoid arthritis [74], autoimmune hepatitis [75], primary biliary cirrhosis [76], and scleroderma [77]. HSP65 is also implicated in multiple vasculitis-associated systemic autoimmune diseases such as Kawasaki disease [78], Behcet's disease [79], and Takayasu's arteritis [80].

Although the SLC11a1 gene was featured in our discussion, there are several gene defects that are associated with mycobacterial infection and autoimmune disease. Besides SLC11a1, genes with strong mycobacterial susceptibility/ autoimmune associations are the NOD2 gene [81], VDR (vitamin D receptor) gene [82], the LTA (lymphotoxinalpha) gene [83], and the complement $\mathrm{C} 4$ gene [84]. The NOD2 (CARD15) gene has been of interest as different domains of the gene are associated with two aforementioned human diseases: Crohn's and Blau syndrome [43].

The list of diseases in which MAP has been implicated in a causal role is growing. This paper illuminates a parsimonious path linking MAP and a number of autoimmune diseases. The link proposed is mycobacterial HSP65 of MAP.

\section{References}

[1] R. T. Damian, "Molecular mimicry: antigen sharing by parasite and host and its consequences," The American Naturalist, vol. 98, pp. 129-149, 1964.

[2] M. Blank, O. Barzilai, and Y. Shoenfeld, "Molecular mimicry and auto-immunity," Clinical Reviews in Allergy and Immunology, vol. 32, no. 1, pp. 111-118, 2007.

[3] L. McAlister, S. Strausberg, A. Kulaga, and D. B. Finkelstein, "Altered patterns of protein synthesis induced by heat shock of yeast," Current Genetics, vol. 1, no. 1, pp. 63-74, 1979.

[4] M. J. Miller, N. H. Xuong, and E. P. Geiduschek, "A response of protein synthesis to temperature shift in the yeast Saccharomyces cerevisiae," Proceedings of the National Academy of Sciences of the United States of America, vol. 76, no. 10, pp. 5222-5225, 1979.
[5] S. D. Guttman and M. A. Gorovsky, "Cilia regeneration in starved tetrahymena: an inducible system for studying gene expression and organelle biogenesis," Cell, vol. 17, no. 2, pp. 307-317, 1979.

[6] P. M. Kelley and M. J. Schlesinger, "The effect of amino acid analogues and heat shock on gene expression in chicken embryo fibroblasts," Cell, vol. 15, no. 4, pp. 1277-1286, 1978.

[7] S. H. E. Kaufmann, B. Schoel, V. J. D. A. Embden et al., "Heatshock protein 60: implications for pathogenesis of and protection against bacterial infections," Immunological Reviews, no. 121, pp. 67-90, 1991.

[8] W. J. Welch, "How cells respond to stress," Scientific American, vol. 268, no. 5, pp. 56-64, 1993.

[9] B. J. Soltys and R. S. Gupta, "Cell surface localization of the $60 \mathrm{kDa}$ heat shock chaperonin protein (hsp60) in mammalian cells," Cell Biology International, vol. 21, no. 5, pp. 315-320, 1997.

[10] S. H. E. Kaufmann, U. Vath, and J. E. R. Thole, "Enumeration of T cells reactive with Mycobacterium tuberculosis organisms and specific for the recombinant mycobacterial $64-\mathrm{kDa}$ protein," European Journal of Immunology, vol. 17, no. 3, pp. 351357, 1987.

[11] S. Jindal, A. K. Dudani, B. Singh, C. B. Harley, and R. S. Gupta, "Primary structure of a human mitochondrial protein homologous to the bacterial and plant chaperonins and to the 65-kilodalton mycobacterial antigen," Molecular and Cellular Biology, vol. 9, no. 5, pp. 2279-2283, 1989.

[12] C. Y. Turenne, M. Semret, D. V. Cousins, D. M. Collins, and M. A. Behr, "Sequencing of hsp65 distinguishes among subsets of the Mycobacterium avium complex," Journal of Clinical Microbiology, vol. 44, no. 2, pp. 433-440, 2006.

[13] B. Maresca and G. S. Kobayashi, "Hsp 70 in parasites: as an inducible protective protein and as an antigen," Experientia, vol. 50, no. 11-12, pp. 1067-1074, 1994.

[14] M. R. Stanford, E. Kasp, R. Whiston et al., "Heat shock protein peptides reactive in patients with Behcet's disease are uveitogenic in Lewis rats," Clinical and Experimental Immunology, vol. 97, no. 2, pp. 226-231, 1994.

[15] A. Stephanou, D. S. Latchman, and D. A. Isenberg, "The regulation of heat shock proteins and their role in systemic lupus erythematosus," Seminars in Arthritis and Rheumatism, vol. 28, no. 3, pp. 155-162, 1998.

[16] W. van Eden, E. J. Hogervorst, E. J. Hensen, R. van der Zee, J. D. van Embden, and I. R. Cohen, "A cartilage-mimicking T-cell epitope on a $65 \mathrm{~K}$ mycobacterial heat-shock protein: adjuvant arthritis as a model for human rheumatoid arthritis," Current Topics in Microbiology and Immunology, vol. 145, pp. 27-43, 1989.

[17] D. Elias, D. Markovits, T. Reshef, R. Van Der Zee, and I. R. Cohen, "Induction and therapy of autoimmune diabetes in the non-obese diabetic (NOD/Lt) mouse by a $65-\mathrm{kDa}$ heat shock protein," Proceedings of the National Academy of Sciences of the United States of America, vol. 87, no. 4, pp. 1576-1580, 1990.

[18] C. T. Dow, "Mycobacterium avium subspecies paratuberculosisAn environmental trigger of type 1 diabetes mellitus," Journal of Diabetes Mellitus, vol. 2, pp. 88-95, 2012.

[19] M. T. Collins, "Paratuberculosis: review of present knowledge," Acta Veterinaria Scandinavica, vol. 44, no. 3-4, pp. 217-221, 2003.

[20] J. Hermon-Taylor, T. J. Bull, J. M. Sheridan, J. Cheng, M. L. Stellakis, and N. Sumar, "Causation of Crohn's disease by Mycobacterium avium subspecies paratuberculosis," Canadian Journal of Gastroenterology, vol. 14, no. 6, pp. 521-539, 2000. 
[21] J. R. Stabel, “Johne's disease: a hidden threat," Journal of Dairy Science, vol. 81, no. 1, pp. 283-288, 1998.

[22] E. S. Pierce, "Ulcerative colitis and Crohn's disease: is Mycobacterium avium subspecies paratuberculosis the common villain?" Gut Pathogens, vol. 2, no. 1, article 21, 2010.

[23] D. Millar, J. Ford, J. Sanderson et al., "IS900 PCR to detect Mycobacterium paratuberculosis in retail supplies of whole pasteurized cows' milk in England and Wales," Applied and Environmental Microbiology, vol. 62, no. 9, pp. 3446-3452, 1996.

[24] J. L. E. Ellingson, J. L. Anderson, J. J. Koziczkowski et al., "Detection of viable Mycobacterium avium subsp. paratuberculosis in retail pasteurized whole milk by two culture methods and PCR," Journal of Food Protection, vol. 68, no. 5, pp. 966972, 2005.

[25] K. Hruska, M. Bartos, P. Kralik, and I. Pavlik, "Mycobacterium avium subsp. paratuberculosis in powdered infant milk: Paratuberculosis in cattle-the public health problem to be solved," Veterinarni Medicina, vol. 50, no. 8, pp. 327-335, 2005.

[26] R. W. Pickup, G. Rhodes, S. Arnott et al., "Mycobacterium avium subsp. paratuberculosis in the catchment area and water of the river Taff in South Wales, United Kingdom, and its potential relationship to clustering of Crohn's disease cases in the city of Cardiff," Applied and Environmental Microbiology, vol. 71, no. 4, pp. 2130-2139, 2005.

[27] L. Whan, H. J. Ball, I. R. Grant, and M. T. Rowe, "Occurrence of Mycobacterium avium subsp. paratuberculosis in untreated water in Northern Ireland," Applied and Environmental Microbiology, vol. 71, no. 11, pp. 7107-7112, 2005.

[28] S. K. Grewal, S. Rajeev, S. Sreevatsan, and F. C. Michel, "Persistence of Mycobacterium avium subsp. paratuberculosis and other zoonotic pathogens during simulated composting, manure packing, and liquid storage of dairy manure," Applied and Environmental Microbiology, vol. 72, no. 1, pp. 565-574, 2006.

[29] C. O. Gill, L. Saucier, and W. J. Meadus, "Mycobacterium avium subsp. paratuberculosis in dairy products, meat, and drinking water," Journal of Food Protection, vol. 74, no. 3, pp. 480-499, 2011.

[30] A. Beumer, D. King, M. Donohue, J. Mistry, T. Covert, and S. Pfaller, "Detection of Mycobacterium avium subsp. paratuberculosis in drinking water and biofilms by quantitative PCR," Applied and Environmental Microbiology, vol. 76, no. 21, pp. 7367-7370, 2010.

[31] W. Chamberlin, T. Borody, and S. Naser, "MAP-associated Crohn's Disease. MAP, Koch's postulates, causality and Crohn's Disease," Digestive and Liver Disease, vol. 39, no. 8, pp. 792-794, 2007.

[32] M. Feller, K. Huwiler, R. Stephan et al., "Mycobacterium avium subspecies paratuberculosis and Crohn's disease: a systematic review and meta-analysis," Lancet Infectious Diseases, vol. 7, no. 9, pp. 607-613, 2007.

[33] J. L. Mendoza, A. San-Pedro, E. Culebras et al., "High prevalence of viable Mycobacterium avium subspecies paratuberculosis in crohn's disease," World Journal of Gastroenterology, vol. 16, no. 36, pp. 4558-4563, 2010.

[34] R. J. Chiodini, "Crohn's disease and the mycobacterioses: a review and comparison of two disease entities," Clinical Microbiology Reviews, vol. 2, no. 1, pp. 90-117, 1989.

[35] J. J. McFadden, P. D. Butcher, R. Chiodini, and J. HermonTaylor, "Crohn's disease-isolated mycobacteria are identical to Mycobacterium paratuberculosis, as determined by DNA probes that distinguish between mycobacterial species," Journal of Clinical Microbiology, vol. 25, no. 5, pp. 796-801, 1987.

[36] A. V. Singh, S. V. Singh, P. K. Singh, J. S. Sohal, and M. K. Singh, "High prevalence of Mycobacterium avium subspecies paratuberculosis ('Indian bison type') in animal attendants suffering from gastrointestinal complaints who work with goat herds endemic for Johne's disease in India," International Journal of Infectious Diseases, vol. 15, no. 10, pp. 677-683, 2011.

[37] L. A. Sechi, M. Manuela, T. Francesco et al., "Identification of Mycobacterium avium subsp. paratuberculosis in biopsy specimens from patients with Crohn's disease identified by in situ hybridization," Journal of Clinical Microbiology, vol. 39, no. 12, pp. 4514-4517, 2001.

[38] S. A. Naser, G. Ghobrial, C. Romero, and J. F. Valentine, "Culture of Mycobacterium avium subspecies paratuberculosis from the blood of patients with Crohn's disease," The Lancet, vol. 364, no. 9439, pp. 1039-1044, 2004.

[39] S. A. . Naser, M. T. Collins, J. T. Crawford, and J. F. Valentine, "Culture of Mycobacterium avium subspecies paratuberculosis (MAP) from the Blood of Patients with Crohn's disease: a follow-up blind multi center investigation," The Open Inflammation Journal, vol. 2, pp. 22-23, 2009.

[40] L. A. Sechi, A. M. Scanu, P. Molicotti et al., "Detection and isolation of Mycobacterium avium subspecies paratuberculosis from intestinal mucosal biopsies of patients with and without Crohn's disease in Sardinia," American Journal of Gastroenterology, vol. 100, no. 7, pp. 1529-1536, 2005.

[41] T. J. Borody, S. Bilkey, A. R. Wettstein, S. Leis, G. Pang, and S. Tye, "Anti-mycobacterial therapy in Crohn's disease heals mucosa with longitudinal scars," Digestive and Liver Disease, vol. 39, no. 5, pp. 438-444, 2007.

[42] F. A. K. El-Zaatari, S. A. Naser, D. C. Markesich, D. C. Kalter, L. Engstand, and D. Y. Graham, "Identification of Mycobacterium avium complex in sarcoidosis," Journal of Clinical Microbiology, vol. 34, no. 9, pp. 2240-2245, 1996.

[43] C. T. Dow and J. L. Ellingson, "Detection of Mycobacterium avium ss. Paratuberculosis in blau syndrome tissues," Autoimmune Diseases, vol. 2010, Article ID 127692, 5 pages, 2010.

[44] A. S. Lapham, E. S. Phillips, and C. H. Barton, "Transcriptional control of Nramp1: a paradigm for the repressive action of c-Myc," Biochemical Society Transactions, vol. 32, no. 6, pp. 1084-1086, 2004.

[45] S. Wyllie, P. Seu, and J. A. Goss, "The natural resistance-associated macrophage protein 1 Slc11a1 (formerly Nramp1) and iron metabolism in macrophages," Microbes and Infection, vol. 4, no. 3, pp. 351-359, 2002.

[46] D. J. Hackam, O. D. Rotstein, W. J. Zhang, S. Gruenheid, P. Gros, and S. Grinstein, "Host resistance to intracellular infection: mutation of natural resistance-associated macrophage protein 1 (Nramp1) impairs phagosomal acidification," Journal of Experimental Medicine, vol. 188, no. 2, pp. 351-364, 1998.

[47] O. Ruiz-Larrañaga, J. M. Garrido, C. Manzano et al., "Identification of single nucleotide polymorphisms in the bovine solute carrier family 11 member 1 (SLC11A1) gene and their association with infection by Mycobacterium avium subspecies paratuberculosis," Journal of Dairy Science, vol. 93, no. 4, pp. 1713-1721, 2010.

[48] L. M. Korou, E. Liandris, M. Gazouli, and J. Ikonomopoulos, "Investigation of the association of the SLC11A1 gene with resistance/sensitivity of goats (Capra hircus) to paratuberculosis," Veterinary Microbiology, vol. 144, no. 3-4, pp. 353-358, 2010. 
[49] A. C. Purdie, K. M. Plain, D. J. Begg, K. de Silva, and R. J. Whittington, "Candidate gene and genome-wide association studies of Mycobacterium avium subsp. paratuberculosis infection in cattle and sheep: a review," Comparative Immunology, Microbiology and Infectious Diseases, vol. 34, no. 3, pp. 197208, 2011.

[50] V. Roupie, V. Rosseels, V. Piersoel, D. K. Zinniel, R. G. Barletta, and K. Huygen, "Genetic resistance of mice to Mycobacterium paratuberculosis is influenced by Slc11a1 at the early but not at the late stage of infection," Infection and Immunity, vol. 76, no. 5, pp. 2099-2105, 2008.

[51] J. M. Blackwell, S. Searle, H. Mohamed, and J. K. White, "Divalent cation transport and susceptibility to infectious and autoimmune disease: continuation of the Ity/Lsh/Bcg/ Nramp1/Slc1la1 gene story," Immunology Letters, vol. 85, no. 2, pp. 197-203, 2003.

[52] M. Hatta, Ratnawati, M. Tanaka, J. Ito, T. Shirakawa, and M. Kawabata, "Nramp1/Slc1lal gene polymorphisms and host susceptibility to Mycobacterium tuberculosis and M. Leprae in South Sulawesi, Indonesia," Southeast Asian Journal of Tropical Medicine and Public Health, vol. 41, no. 2, pp. 386-394, 2010.

[53] R. Bellamy, C. Ruwende, T. Corrah, K. P. W. J. McAdam, H. C. Whittle, and A. V. S. Hill, "Variations in the NRAMP1 gene and susceptibility to tuberculosis in West Africans," The New England Journal of Medicine, vol. 338, no. 10, pp. 640-644, 1998.

[54] A. Dubaniewics, S. E. Jamieson, M. Dubaniewicz-Wybieralska, M. Fakiola, N. E. Miller, and J. M. Blackwell, "Association between SLC11A1 (formerly NRAMP1) and the risk of sarcoidosis in Poland," European Journal of Human Genetics, vol. 13, no. 7, pp. 829-834, 2005.

[55] O. Ates, L. Dalyan, B. Musellim et al., "NRAMP1 (SLC11A1) gene polymorphisms that correlate with autoimmune versus infectious disease susceptibility in tuberculosis and rheumatoid arthritis," International Journal of Immunogenetics, vol. 36, no. 1, pp. 15-19, 2009.

[56] H. S. Mohamed, M. E. Ibrahim, E. N. Miller et al., "SLC11A1 (formerly NRAMP1) and susceptibility to visceral leishmaniasis in the Sudan," European Journal of Human Genetics, vol. 12, no. 1, pp. 66-74, 2004.

[57] M. J. Kotze, J. N. De Villiers, R. N. Rooney et al., "Analysis of the NRAMP1 gene implicated in iron transport: association with multiple sclerosis and age effects," Blood Cells, Molecules, and Diseases, vol. 27, no. 1, pp. 44-53, 2001.

[58] M. Gazouli, L. Sechi, D. Paccagnini et al., "NRAMP1 polymorphism and viral factors in sardinian multiple sclerosis patients," Canadian Journal of Neurological Sciences, vol. 35, no. 4, pp. 491-494, 2008.

[59] M. Gazouli, V. Atsaves, G. Mantzaris et al., "Role of functional polymorphisms of NRAMP1 gene for the development of Crohn's disease," Inflammatory Bowel Diseases, vol. 14, no. 10, pp. 1323-1330, 2008.

[60] R. Kotlowski, C. N. Bernstein, M. S. Silverberg, and D. O. Krause, "Population-based case-control study of alpha 1antitrypsin and SLC11A1 in Crohn's disease and ulcerative colitis," Inflammatory Bowel Diseases, vol. 14, no. 8, pp. 11121117,2008

[61] L. A. Sechi, M. Gazouli, L. E. Sieswerda et al., "Relationship between Crohn's disease, infection with Mycobacterium avium subspecies paratuberculosis and SLC11A1 gene polymorphisms in Sardinian patients," World Journal of Gastroenterology, vol. 12, no. 44, pp. 7161-7164, 2006.

[62] D. Paccagnini, L. Sieswerda, V. Rosu et al., "Linking chronic infection and autoimmune diseases: Mycobacterium avium subspecies paratuberculosis, SLC11A1 polymorphisms and type-1 diabetes mellitus," PLoS ONE, vol. 4, no. 9, Article ID e7109, 2009.

[63] K. Takahashi, J. Satoh, Y. Kojima et al., "Promoter polymorphism of SLC11A1 (formerly NRAMP1) confers susceptibility to autoimmune type 1 diabetes mellitus in Japanese," Tissue Antigens, vol. 63, no. 3, pp. 231-236, 2004.

[64] G. S. Eisenbarth, "Type I diabetes mellitus. A chronic autoimmune disease," The New England Journal of Medicine, vol. 314, no. 21 , pp. 1360-1368, 1986.

[65] C. T. Dow, "Paratuberculosis and type I diabetes -mapping the TRIGR," in Proceedings of the 8th International Colloquium on Paratuberculosis, August 2005, http://www.paratuberculosis .org/pubs/proc8/abst3b_o20.htm.

[66] V. Rosu, N. Ahmed, D. Paccagnini et al., "Specific immunoassays confirm association of Mycobacterium avium subsp. paratuberculosis with type-1 but not type-2 diabetes mellitus," PLoS ONE, vol. 4, no. 2, Article ID e4386, 2009.

[67] A. Cossu, V. Rosu, D. Paccagnini, D. Cossu, A. Pacifico, and L. A. Sechi, "MAP3738c and MptD are specific tags of Mycobacterium avium subsp. paratuberculosis infection in type I diabetes mellitus," Clinical Immunology, vol. 141, pp. 49-57, 2011.

[68] L. A. Sechi, V. Rosu, A. Pacifico, G. Fadda, N. Ahmed, and S. Zanetti, "Humoral immune responses of type 1 diabetes patients to Mycobacterium avium subsp. paratuberculosis lend support to the infectious trigger hypothesis," Clinical and Vaccine Immunology, vol. 15, no. 2, pp. 320-326, 2008.

[69] C. T. Dow, "Paratuberculosis and Type I diabetes Is this the trigger?” Medical Hypotheses, vol. 67, no. 4, pp. 782-785, 2006.

[70] M. D'Amore, S. Lisi, M. Sisto, L. Cucci, and C. T. Dow, "Molecular identification of Mycobacterium avium subspecies paratuberculosis in an Italian patient with Hashimoto's thyroiditis and Melkersson-Rosenthal syndrome," Journal of Medical Microbiology, vol. 59, no. 1, pp. 137-139, 2010.

[71] M. Sisto, L. Cucci, M. D’Amore, T. C. Dow, V. Mitolo, and S. Lisi, "Proposing a relationship between Mycobacterium avium subspecies paratuberculosis infection and Hashimoto's thyroiditis," Scandinavian Journal of Infectious Diseases, vol. 42, no. 10, pp. 787-790, 2010.

[72] D. Cossu, E. Cocco, D. Paccagnini et al., "Association of Mycobacterium avium subsp. paratuberculosis with multiple sclerosis in sardinian patients," PLoS ONE, vol. 6, no. 4, Article ID e18482, 2011.

[73] W. N. Jarjour, B. D. Jeffries, J. S. Davis, W. J. Welch, T. Mimura, and J. B. Winfield, "Autoantibodies to human stress proteins: a survey of various rheumatic and other inflammatory diseases," Arthritis and Rheumatism, vol. 34, no. 9, pp. 1133-1138, 1991.

[74] K. D. Moudgil, T. T. Chang, H. Eradat et al., "Diversification of $\mathrm{T}$ cell responses to carboxy-terminal determinants within the $65-\mathrm{kD}$ heat-shock protein is involved in regulation of autoimmune arthritis," Journal of Experimental Medicine, vol. 185, no. 7, pp. 1307-1316, 1997.

[75] M. Miyata, A. Kogure, H. Sato et al., "Detection of antibodies to $65 \mathrm{KD}$ heat shock protein and to human superoxide dismutase in autoimmune hepatitis-molecular mimicry between $65 \mathrm{KD}$ heat shock protein and superoxide dismutase," Clinical Rheumatology, vol. 14, no. 6, pp. 673-677, 1995.

[76] L. Vilagut, A. Parés, O. Viñas, J. Vila, M. T. Jiménez De Anta, and J. Rodés, "Antibodies to mycobacterial 65-kD heat shock protein cross-react with the main mitochondrial antigens in patients with primary biliary cirrhosis," European Journal of Clinical Investigation, vol. 27, no. 8, pp. 667-672, 1997. 
[77] M. G. Danieli, M. Candela, A. M. Ricciatti et al., "Antibodies to mycobacterial $65 \mathrm{kDa}$ heat shock protein in systemic sclerosis (scleroderma)," Journal of Autoimmunity, vol. 5, no. 4, pp. 443-452, 1992.

[78] S. Yokota, K. Tsubaki, T. Kuriyama et al., "Presence in Kawasaki disease of antibodies to mycobacterial heat-shock protein HSP65 and autoantibodies to epitopes of human HSP65 cognate antigen," Clinical Immunology and Immunopathology, vol. 67, no. 2, pp. 163-170, 1993.

[79] H. Direskeneli and G. Saruhan-Direskeneli, "The role of heat shock proteins in Behçet's disease," Clinical and Experimental Rheumatology, vol. 21, no. 4, pp. S44-S48, 2003.

[80] A. Aggarwal, M. Chag, N. Sinha, and S. Naik, "Takayasu's arteritis: role of Mycobacterium tuberculosis and its $65 \mathrm{kDa}$ heat shock protein," International Journal of Cardiology, vol. 55, no. 1, pp. 49-55, 1996.

[81] M. H. Shaw, T. Reimer, Y. G. Kim, and G. Nuñez, "NOD-like receptors (NLRs): bona fide intracellular microbial sensors," Current Opinion in Immunology, vol. 20, no. 4, pp. 377-382, 2008.

[82] P. Selvaraj, "Vitamin D, vitamin D receptor, and cathelicidin in the treatment of tuberculosis," Vitamins and Hormones, vol. 86, pp. 307-325, 2011.

[83] D. R. Roach, H. Briscoe, B. Saunders, M. P. France, S. Riminton, and W. J. Britton, "Secreted lymphotoxin- $\alpha$ is essential for the control of an intracellular bacterial infection," Journal of Experimental Medicine, vol. 193, no. 2, pp. 239-246, 2001.

[84] E. S. Samano, L. M. Ribeiro, R. G. Gorescu, K. C. Rocha, and A. S. Grumach, "Involvement of C4 allotypes in the pathogenesis of human diseases," Revista do Hospital das Clinicas, vol. 59, no. 3, pp. 138-144, 2004. 


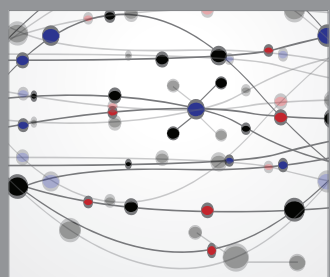

The Scientific World Journal
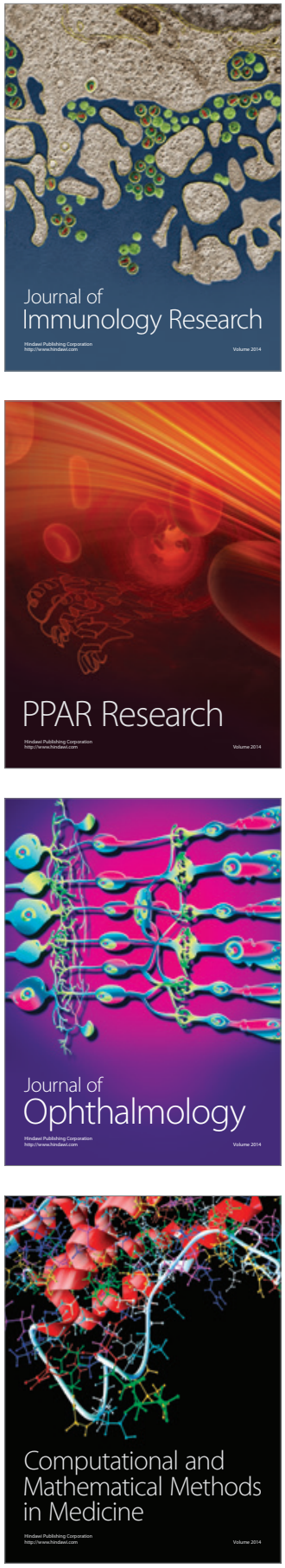

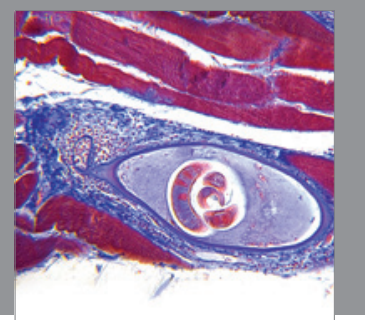

Gastroenterology

Research and Practice
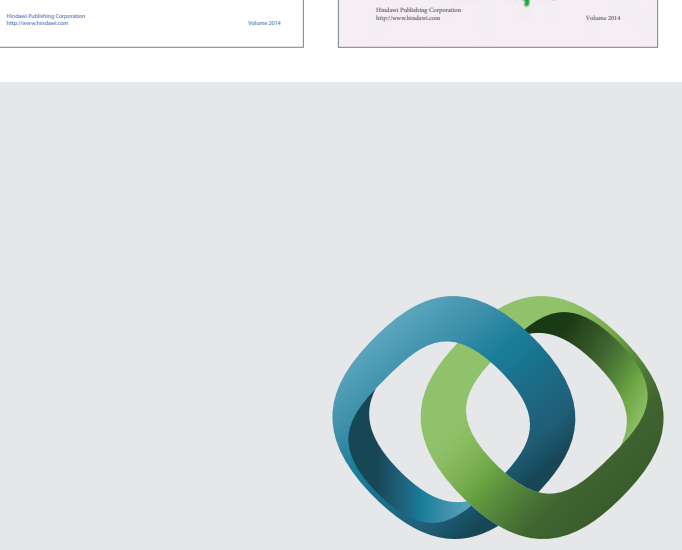

\section{Hindawi}

Submit your manuscripts at

http://www.hindawi.com
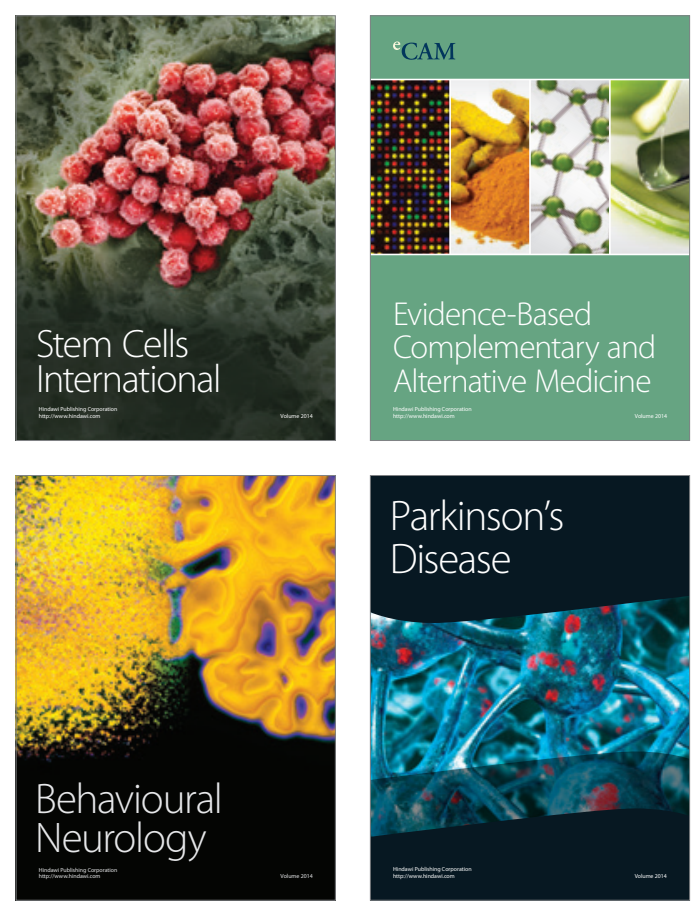

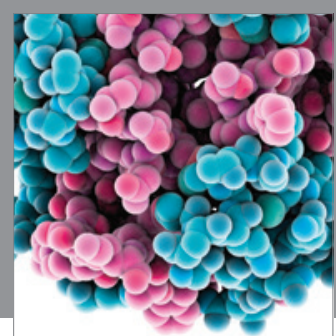

Journal of
Diabetes Research

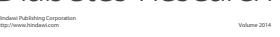

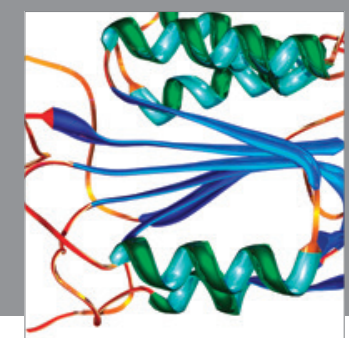

Disease Markers
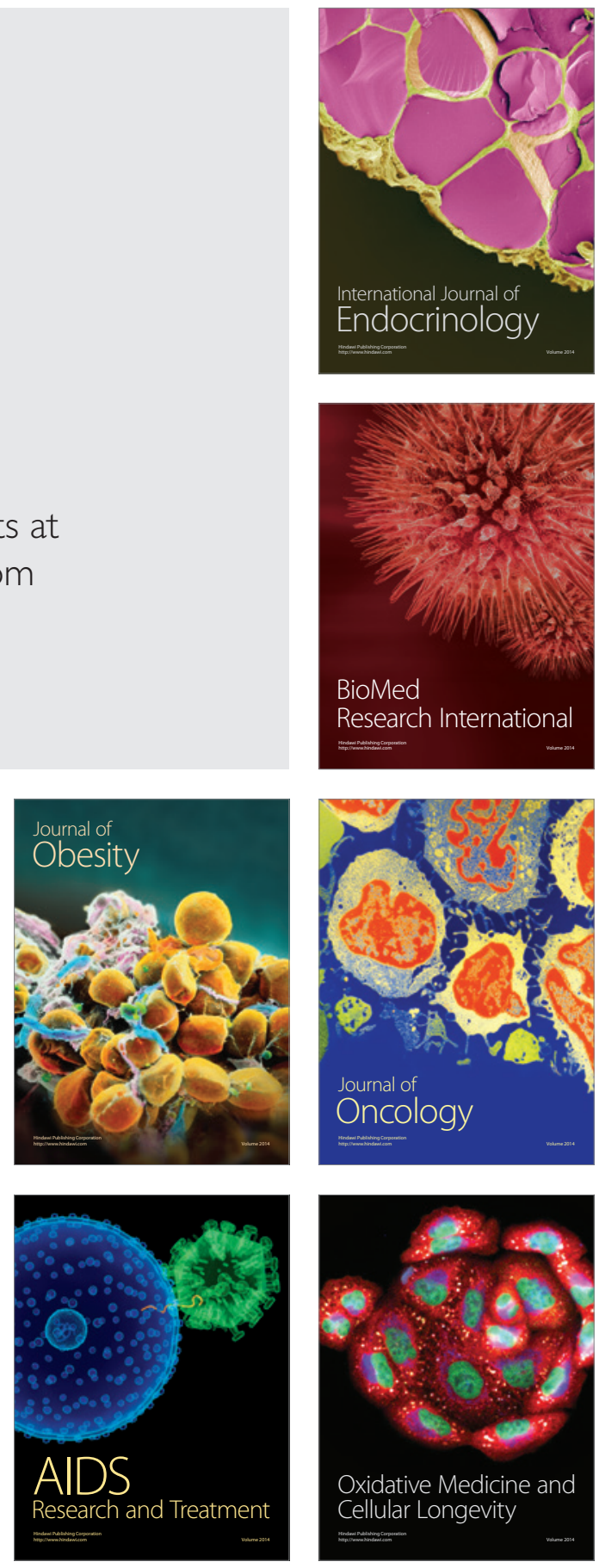